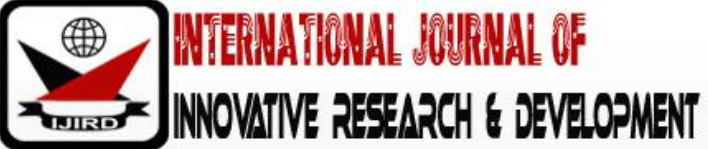

ISSN 2278-0211 (Online)

\section{Analysis of Technical Efficiency of Smallholder Indigenous Chicken Keepers in Meru County, Kenya}

\author{
Dr. David Kimenchu Mugambi \\ Chief Officer, Department of Agriculture, Livestock Development and Fisheries, \\ County Government of Meru, Kenya
}

\begin{abstract}
:
The objective of this study was to analyze the technical efficiency of smallholder indigenous chicken keepers in Meru County of Kenya. The County lies on the Eastern side of Kenya's Central highlands at $0^{\circ}, 3800^{\circ}$ E, and covers 6936.4 $\mathrm{Km}^{2}$.Data were collected through a cross-sectional survey from 90 (30 Ng'onyi, $30 \mathrm{Ntalami}$ and 30 Kangeta villages) randomly sampled farms using semi-structured questionnaires. Data analysis was carried out using the SPSS and Frontier 4.1 c computer softwares. Stochastic frontier production function was estimated using the maximum likelihood estimation technique. The farms were characterized and their technical efficiencies estimated. Results revealed that the indigenous chicken keeping households owned an average of 17 at a time, after selling out about 15 for incomes. They produced an average of 500 eggs per annum, with each hen producing about 45. Households consumed both eggs and chicken. The value of the sold and consumed eggs as well as sold chicken was Ksh. 17715 (1 USD= Ksh. 107). Most household heads were married (85\%), with $70 \%$ aged between 36 and 65 years. A majority of the farmers were literate (90\%). Over 75\% of the households had between 3 and 6 persons. The average size of land owned was 1.33 acres. It's only $9 \%$ of farmers who were satisfied with farming. Decrease in land size prompted households to increase the flock sizes (tended towards commercialization). The number of live chickens sold correlated positively with increase in the number of indigenous chickens kept, but inversely proportional to land size owned. The study established that farmers operated at 74.83\% technical efficiency implying that they could increase their flock from an average of 17 to 23 through better use of available resources, given the current state of technology without extra cost. It was recommended that since market for live indigenous chicken was in existence, approaches that assist in improving the chicken population be adopted. Use of genetically improved indigenous breeds, improvement of chicken housing, supplementing the free-range feed with concentrate feed, improving egg hatchability and chick survival, require being considered. Improving farmer knowledge through better public extension service would be a pre-requisite for increased number of indigenous chicken flock size.
\end{abstract}

Keywords: Technical efficiency, indigenous chicken, production, laying clutch, eggs

\section{Introduction}

Poultry keeping is a key economic activity throughout the developing world, making a substantial contribution to household food security. Poultry provide a major income-generating activity from the sale of birds and eggs. Chicken meat and eggs provide a readily available, high-quality source of proteins, vitamins and micronutrients (Technoserve and KARI, Undated).Commercial indigenous poultry production is becoming a fast-supplementary income-generating enterprise for rural farmers. The combination of growth in human populations, a shift toward urban living and increasing incomes is contributing to higher demand for non-staple foods such as chicken, whose meat is inexpensive and highly sought-after animal protein source (Olwande, 2010).

Poultry is increasing in importance globally, including in Sub-Saharan Africa and South Asia. The demand for exotic chickens is declining worldwide due to a majority of the consumers opting for meat of indigenous chickens (Siyaya \& Masuku, 2013).It is claimed to be tastier and better suited to the traditional way of prolonged cooking (Mapiyeet al, 2008).This is an opportunity for the developing world countries. However, both supply and per capita consumption of chicken in the developing world is low at the moment. Global production of chicken meat has increased by $42 \%$ in a decade from just under 80 million MT in 2007 to 109 million in 2017. Over the same period, Africa grew by $46 \%$, albeit from a small base, comprising just $5 \%$ of global chicken production (FAO, 2019). Although sub-Saharan Africa makes up approximately 13\% of the global population, it produces less than 5\% of global egg production (Guyonnet, 2017).

Africa has remained a continent characterized by under production and consumption of chicken meat. While the global per capita consumption of chicken meat is averaging $15.2 \mathrm{~kg}$, Israel's is 67.4 and Kenya's is 0.67 (FA0, 2017). Kenya's per capita consumption is the third in Africa, after the republic of South Africa and Nigeria. This indicates that Africa, with its rising incomes per capita, growing urbanization and increasing population, requires huge leaps in chicken 
production. Indigenous chickens in sub-Saharan Africa and other parts of the world have not attained their full production potential due to exposure to risk factors that constrain their survival and productivity (Sekeroglu and Akisimsek, 2009). In Africa, traditional poultry husbandry has the following characteristics; (a) the birds range freely during the day and are gathered at night into a basic shelter to avoid losses through predators, (b) the feed is limited to what the birds can find by themselves(insects, seeds, kitchen wastes), but sometimes a supplement is given depending on the availability of the feedstuffs used in the household, (c) the productivity of chickens production systems in general is low and, (d) high mortality rates are registered (Mutua, 2018).This makes it hard for Africa to meet its own indigenous chicken demand.

Most households in Kenya's arid areas keep beef cattle and shoats. They keep a minimal number of indigenous chicken because their populations are low and live far away from the urban centres. Their pastoralism mode of living makes it difficult to migrate with chicken. A huge population of the indigenous chicken is kept by mixed crop-livestock farmers in the semi-arid areas. Most of these keepers live less than $50 \mathrm{Km}$ away from major towns where demand for indigenous chicken is high. Kenya's human population, just like in other African countries, has continued to increase both in the urban and rural areas. Per capita household land size is inversely decreasing with human population increase. The country has a chicken population of 38816238 birds (RoK, 2019); 30320632 (78\%) indigenous chicken,5 580766 exotic layers and 2 914840 exotic broilers. The country's human population (47,564,300 persons, 2019) is about 10 million above that of poultry, clearly agreeing with the data on consumption of less than one kilogram of chicken meat per capita. The indigenous chicken range freely in the household compound and find much of their own food, getting supplementary amounts from the householder. The result is that both production and productivity are below potential, with losses and wastage remaining high.

The above indicated scenario of increasing human population, increased desire for living in the urban areas and enhanced incomes, imply increased demand for indigenous chicken. Unfortunately, household land sizes that could be used to raise free range chicken is reducing due to increased subdivisions. Increased supply of indigenous chicken shall henceforth, continue depending on how efficiently the available resources are utilized. This study sought to assess the technical efficiency of indigenous chicken production among the rearing households in Meru County in Kenya, with a focus on the number of indigenous chickensowned. Technical efficiency estimation provides an indication of the percentage by which potential output could be increased in relation to the corresponding production frontier (Kokkinou and Geo, 2009). A producer is hardly fully productively efficient. The difference can be explained in terms of allocative and technical inefficiencies, as well as a range of unforeseen exogenous shocks (Reifschneider and Stevenson, 1991).

Farrell (1957) provided a measurement application on U.S. agriculture and was the first to measure productive efficiency empirically. His study on efficiency measurement led to the development of several approaches to efficiency and productivity analysis. These approaches include: the stochastic frontier production (Aigner et al, 1977; Meeusen and van den Broeck, 1977), distribution free approach (DFA) and the thick frontier approach (TFA) (all parametric), and Data Envelopment Analysis (DEA) (Charnes et al, 1978) and the free disposal hull (FDH), (both non-parametric). In parametric approaches, a functional form is assumed and econometric methods are used to estimate it. A functional form is imposed on the production function and assumptions about the data are made (Chirwa, 2007). The production function estimation is mostly performed by employment of stochastic frontier analysis (SFA), which accounts for both inefficiency and random noise effects. This study used the parametric stochastic frontier production approach.

\section{Materials and Methods}

\subsection{Description of Study Area, Sampling Technique, Data Sources and Collection Method}

Meru County lies on the Eastern side of Kenya's Central highlands at $0^{\circ}, 3800^{\circ} \mathrm{E}$, and covers $6936.4 \mathrm{Km}^{2}$. Itsrain seasons are March to May and October to December with annual rainfall totals ranging in-between 500- $2600 \mathrm{~mm}$. The temperature ranges between 11.4-28 $\mathrm{C}$ (Jaetzoldet al, 2007). The county bordersMt. Kenya and isideal for both crop farming and livestock rearing. According to the latest Kenya's population census (RoK, 2019), Meru countyhas $1,545,714$ persons.

The sample for this study (90 indigenous chicken keepers) was drawn from three randomly selected villages in Meru county; Ng'onyi (Imenti North Sub-County), Ntalami (Tigania west Sub-County) and Kangeta (Igembe Central SubCounty). Meru County is constituted of Imenti, Tigania and Igembe regions. The target population for the study constituted of indigenous chicken keepers in Meru County. The survey was undertaken in November 2019, with 30 farmers being randomly selected from each of the three villages.

A descriptive survey technique using semi-structured questionnaires was used for data collection. Data on the following was recorded: total number of chicken in the household; land size owned (acres); total number of chicken kept the previous year; average price of an adult chicken; number of eggs laid by a hen in a laying period; number of eggs consumed by the family over the last one year; total number of eggs sold over the last one year; price of one egg; total number of chicken sold over the last one year; household head's marital status, his/her chronological age, his/her highest level of attained formal education, household size, and his/her level of satisfaction with farming in general. All the data were obtained from the farmer's response, except the data on the current number of indigenous chickens which were obtained by actual counting.

\subsection{Stochastic Frontier Production Functions}

The stochastic frontier production function has two error terms one to account for random effects (e.g., measurement errors in the output variable, weather conditions, diseases, etc. and the combined effects of 
unobserved/uncontrollable inputs on production) and another to account for technical inefficiency in production. The stochastic frontier production function can be written as;

$Y_{i}=f\left(x_{i} ; \beta\right)+\varepsilon_{i}$ where, $\mathrm{i}=1,2, \ldots, \mathrm{N}(1)$

$\varepsilon_{i}=v_{i}-u_{\mathrm{i}}(2)$

where, $Y_{i}$ represents the output of the $i^{\text {th }}$ farm; $f\left(x_{i} ; \beta\right)$ is a suitable function (such as Cobb-Douglas or translog production functions) of vector, $x_{i}$, of inputs for the $i^{\text {th }}$ farm and a vector, $\beta$, of unknown parameters. $\varepsilon i$ is an error term made up of two components: $v_{i}$ is a random error having zero mean, $N\left(0 ; \sigma_{v}^{2}\right)$ which is associated with random factors such as measurement errors in production and weather which the farmer does not have control over. It is assumed to be independent of $\mathrm{u}_{\mathrm{i}}$. On the other hand, $\mathrm{u}_{\mathrm{i}}$ is a non-negative random variable representing the inefficiency, which is assumed to be distributed independently and obtained by truncation at zero of the $N\left(\mu_{\mathrm{i}}, \sigma_{\mathrm{u}}{ }^{2}\right)$ distribution.

\subsection{Empirical Model for Technical Efficiency Estimation}

In this study, estimation of the technical efficiency of indigenous chicken keeping households was the target. A Cobb-Douglas functional form was assumed in specifying the production function. The functional form allows the focus to be on the error term (Kumbhakar and Lovell, 2000).

According to Khai and Yabe (2011) there are many functional forms for estimating the physical relationship between inputs and output, but the Cobb-Douglas functional form is preferred to other forms, especially if there are three or more independent variables in the model.

The maximum likelihood estimates of the parameters of the production function were estimated using the procedure in the FRONTIER 4.1c (Coelli, 1996) econometric software. The function was specified as;

In $\mathrm{Yi}=\mathrm{K}_{0}+\mathrm{K}_{1} \ln \mathrm{X}_{\mathrm{ij}}+\mathrm{K}_{2} \ln \mathrm{X}_{2 \mathrm{ij}}+\mathrm{K}_{3} \ln \mathrm{X}_{3} \mathrm{ij}+\mathrm{K}_{4} \ln \mathrm{X}_{4 \mathrm{ij}}+\mathrm{K}_{5} \ln \mathrm{X}_{5 \mathrm{ij}}+\mathrm{K}_{6} \ln \mathrm{X}_{6 \mathrm{ij}}+\mathrm{K}_{7} \ln \mathrm{X}_{7 \mathrm{ij}}+\mathrm{K}_{8} \ln \mathrm{X}_{8 \mathrm{ij}}+\mathrm{Vij}_{\mathrm{ij}}-\mathrm{uij}$ (3)

Where;

ln represents logarithm to base e; subscripts ij refers to the $\mathrm{j}^{\text {th }}$ observation of the $\mathrm{i}^{\text {th }}$ farm; $\mathrm{Y}$ is the total number of chicken; $\mathrm{X}_{1}$ represents the landsize (acres); $\mathrm{X}_{2}$ is the total number of chicken kept over the last one year; $\mathrm{X}_{3}$ represents the price of an adult chicken (KSh.); $\mathrm{X}_{4}$ represents the number of eggs a chicken lays in a laying period (Clutch); $\mathrm{X}_{5}$ is the number of eggs the household consumed over the last one year; $\mathrm{X}_{6}$ represents the total number of eggs sold over the last one year; $\mathrm{X}_{7}$ is the average price of an egg(Ksh.); and $\mathrm{X}_{8}$ represents the total number of live chicken sold by the household over the last one year.

\section{Results}

\subsection{Characterization of Smallholder Indigenous Chicken Keepers in Meru County, Kenya}

Table 1 below summarizes the data on study variables used to characterize the smallholder indigenous chicken keepers in Meru county in Kenya.

\begin{tabular}{|c|c|c|}
\hline Item Description & Mean $(\mathrm{N}=90)$ & Standard Deviation and Range \\
\hline Number of chickens kept & 16.38 & $20.48\left(158^{a}\right)$ \\
\hline Land size owned (acres) & 1.33 & $1.36(6.99)$ \\
\hline Number of chickens owned last year & 19.67 & $25.28(150)$ \\
\hline Price of live chicken (KSh.) & 679.67 & $201.22(1000)$ \\
\hline Number of eggs laid per laying period & 14.36 & $3.43(25)$ \\
\hline Number of eggs consumed at home last year & 275.72 & $363.73(2800)$ \\
\hline Number of eggs sold last year & 225.14 & $443.99(2520)$ \\
\hline Price per egg (KSh.) & 15.17 & $2.54(10)$ \\
\hline Number of chickens sold last year & 14.07 & $14.92(123)$ \\
\hline $\begin{array}{c}\text { Marital status of Household head (1=Youth, } \\
\text { 2=Single parent and 3=Married) }\end{array}$ & $\begin{array}{c}2.79 \text { (Married }=85.6 \% \\
\text { Singles }=7.8 \% \text {, Youth }=6.7 \%)\end{array}$ & $0.55(2)$ \\
\hline $\begin{array}{c}\text { Age of farmer (years) }(1=18-25 ; 2=36-45 ; \\
3=46-65 ; 4=\text { over } 65 \text { years of age })\end{array}$ & $\begin{array}{c}2.27 \\
\text { (Youth }=24.4 \% ; \\
36-45 \text { years }=30 \% ; 46=65 \\
\text { years }=40 \% ; \text { Over } 65 \\
\text { years }=5.6 \% \text { ) }\end{array}$ & $0.90(3)$ \\
\hline $\begin{array}{l}\text { Education level attained by the farmer (1=No } \\
\text { formal education; } 2=\text { primary level; } \\
3=\text { secondary school level; } 4=\text { Tertiary level } \\
\text { and } 5=\text { University level of education) }\end{array}$ & $\begin{array}{c}2.56 \\
\text { (Informal=8.9\%; } \\
\text { Primary }=53.3 \% ; \\
\text { Secondary=24.4\%; } \\
\text { Tertiary=10\%; } \\
\text { University }=3.3 \% \text { ) }\end{array}$ & $0.91(4)$ \\
\hline $\begin{array}{l}\text { Household size (ranged between } 1 \text { and } 8 \\
\text { persons) }\end{array}$ & $\begin{array}{l}4.46(75 \% \text { were between } 3 \& \\
6 \text { No.) }\end{array}$ & $1.68(7)$ \\
\hline $\begin{array}{l}\text { Level of satisfaction of the farming activity } \\
\text { (1=Dissatisfied; } 2=\text { Fairly satisfied and } \\
\text { 3=Satisfied) }\end{array}$ & $\begin{array}{c}\text { 1.54 } \\
\text { (Satisfied }=8.9 \% \\
\text { Fairly satisfied }=36.7 \% \\
\text { Dissatisfied }=54.4 \% \text { ) }\end{array}$ & $0.66(2)$ \\
\hline
\end{tabular}

Table 1: A Summary of Descriptive Statistics of Identified Study Variables. ${ }^{A}$ the Range in Parenthesis 


\subsection{Production frontier estimates}

The table below summarizes the results obtained from the estimated indigenous chicken production frontier model.

\begin{tabular}{|c|c|c|c|}
\hline Variable & Coefficient & Standard Error & t-ratio \\
\hline Constant & 0.57 & 1.12 & 0.51 \\
\hline Size of land owned & -0.17 & 0.10 & $1.75^{*}$ \\
\hline Number of chickens owned last year & -0.02 & 0.08 & 0.21 \\
\hline Price of Chicken & -0.03 & 0.11 & 0.31 \\
\hline Number of eggs laid in a laying season & -0.25 & 0.29 & -0.85 \\
\hline Number of eggs consumed last year & -0.02 & 0.10 & -0.18 \\
\hline Number of eggs sold last year & -0.01 & 0.05 & -0.21 \\
\hline Price of Eggs & 0.57 & 0.57 & 1.00 \\
\hline Number of chickens sold last year & 0.30 & 0.12 & $2.51^{*}$ \\
\hline \multicolumn{4}{|c|}{ Variance Parameters } \\
\hline$\sigma^{2}$ (sigma-squared) & 0.13 & 0.02 & $6.1^{* *}$ \\
\hline$\gamma$ (gamma) & 0.10 & 0.64 & $1.93^{*}$ \\
\hline
\end{tabular}

Table 2: Mles of Cobb-Douglas Stochastic Frontier Model for Meru County Chicken Keeping Farms

** * Significance Level at 1\% And 5\% Respectively

Diagnostic Statistics: Log Likelihood Function =-35.10, LR Test of the One-Sided Error = 5.07,

Note: All Explanatory Variables Are In Natural Logarithms.

Source: Computations from Frontier 4.1c

\subsection{Technical Efficiency Levels}

Chicken keeping farm efficiencies range between 60.7 and 91.3\%, with mean estimate of 74.83\% (table 3). This mean efficiency level indicates that only 25.17percent of the output can be attributed to wastage. Table 3 shows the frequency distribution of the chicken keeping farm efficiencies. Over $97 \%$ of the chicken keeping farms operated at efficiencies between 60 and $90 \%$.

\begin{tabular}{|c|c|}
\hline Percentage Class & Proportion (\%) \\
\hline $0-60$ & $0(0)$ \\
\hline $60.1-70$ & $30(27)$ \\
\hline $70.1-80$ & $44.4(40)$ \\
\hline $80.1-90$ & $23.3(21)$ \\
\hline $90.1-100$ & $2(2)$ \\
\hline Additional Information on the Technical Efficiencies \\
\hline Maximum TE & 91.3 \\
\hline Minimum TE & 60.7 \\
\hline Mean TE & 74.83 \\
\hline Std. Deviation & 7.09 \\
\hline
\end{tabular}

Table 3: Frequency of Technical Efficiencies among Chicken Keeping Farms in Meru County

The Frequencies Are in Parenthesis

\section{Discussion}

In a typical rural village in Kenya's semi-arid areas, poultry lay eggs in simple nests, spend their night in undefined houses or perching on trees, and spend much of the day scavenging for feed. They spend a large proportion of their time scratching to expose hidden food. Feed sourced in this manner is rarely adequate for optimal chicken flock performance. In this study, a farmer was found with an average of 17 indigenous chicken, including the cocks, hens, pullets and chicks. The average number of chickens owned the previous year was 20 after selling out 15 . This number of chickens is much higher than what Thwala (2012) found in Swaziland. He found households keeping about five indigenous chickens through subsistence farming practices. Just like the households in Meru County, Swazi households kept their chickens under scavenging production systems with limited application of management interventions to improve productivity. In Kenya, Mailuet al., (2012) reported the average flock size of 16 chickens with wide variations among regions (range 10-21 chickens).In Uganda, the size varies anywhere between 17-22 birds (Ssewannyana et al., 2006), while in Morocco, there are 11 chicken per household (Benabdeljelil et al., 2001) and between 15-20 birds in Botswana (Badubi et al., 2006).

An indigenous chicken was sold at average of Ksh.680, which translated to Ksh. 10, 200 over the year. Each hen laid 15 eggs par laying period (clutch), implying that it laid about 45 eggs in a year. According to FAO (2004), indigenous chicken lay an average of three to four clutches of 12 to 15 eggs in a year, with more eggs laid at crop harvest time because more feed is available. Msoffe etal., (2002) in Tanzania, reported mean flock egg number/clutch/bird, clutch number/bird/year and egg number/bird/year as $17.7 \pm 0.25,2.6 \pm 0.06$ and $46.4 \pm 0.86$. High hatchability rates of $100 \%$, $77 \%$ and 60-65\% have been observed in Tanzania (Msami et al, 2002), Senegal (Missohou et al., 2002) and India (Mandal et al., 2006), respectively. Low productivity of indigenous chicken is associated with low egg production performance, production of small sized eggs, slow growth rate, late maturity, small clutch size, an instinctive inclination to broodiness 
and high mortality of chicks (Fisseha et al, 2010). On average, the reproductive cycle of an indigenous hen consists of a 15day laying phase, a 21day incubation phase and about 60 days of brooding, this translating to about three cycles a year. With hatchability and survivability levels of about 60\% (Muchadeyi et al., 2005) and chick mortality of between 50-70\%, the expected contribution of the poultry sub-sector is minimal, against potential.

Most mortalities are caused by poor health management and predators such as dogs, cats, snakes, eagles, hawks and thieves. Predation can be reduced by close monitoring of the free ranging chickens during scavenging periods and keeping them in proper houses during the night. Hunting, trapping or poisoning of predators can also lessen predation levels (Muchadeyi et al.,2005). Poor health management resulting in high mortality rates and compromised productive performance characterize most smallholder chicken production systems in the rural areas. Improved flock health and controlled predation can improve the performance of the indigenous chicken flocks. This performance could be in increased hatchability, chick survival, growth rate, clutch size, egg and flock sizes.

On average, the households sold out 225 eggs over the previous year. The price of an egg averaged Ksh. 15. The total average receipts from the sale of eggs were Ksh. 3, 375. It is worth noting that the household consumed 276 eggs over the previous year, valued at Ksh. 4, 140. The total value gained by the households last year (receipts from sales of chickens and eggs as well as the value of what was consumed) was Ksh. 17,715. According to the Kenya national bureau of statistics (KNBS, 2018), rural households earning more than Ksh. 3, 252 a month as living above the poverty line.

Marketing of live birds is common where indigenous chicken production system is practiced. In areas where markets are a problem, farmers are forced to keep the birds longer and this increases the costs of production by increasing the amount of feed required to keep the birds alive (Pedersen, 2002). Organized marketing is largely non-existent in many areas. Farmers are recommended to organize themselves into groups and set satellite centres with electricity driven refrigerators so that they use the cold chain system of marketing. Selling cold dressed chickens ensures farmers do not have to keep live chickens for unnecessarily long periods of time. It is important to organize farmers into 'chicken commodity groups' which will have more authority over their produce (Kusina and Kusina, 1999). Furthermore, small processing, packaging and value addition plants can also be set up at these centres to assist during times when there are large volumes of chickens. The advantages of farmer organization also lie in the selling of products in bulk, attracting big markets and enjoying economies of scale. The marketing system for indigenous birds in Kenya is described as unorganized, weak and indeterminate (Munyasi et al., 2009).

Meru County is a rural region in Kenya, with residents clinging unto the cultural beliefs about marriage. Over $85 \%$ of the respondents were married with only $8 \%$ being single (widowed/divorced/single by choice). The unmarried farmers constituted only 7. It was established that $70 \%$ of the respondents were aged between 36 and 65 years. Those above this age constituted only $5.6 \%$. These proportions were expected because that is how the population structure appears. The youth formed a quarter of the respondents. The largest proportion of the respondents had attained either primary (53\%) or secondary (24\%) school level of education. Those without formal education constituted only $9 \%$ and those with above the secondary school level were $13.3 \%$.

The household size averaged 5 (4.46) persons with 75\% of the households being between 3 and 6 persons. The highest number of persons in a household was 8. The average size of land owned was 1.33 acres. When asked about their satisfaction on farming in general (choices; satisfied, fairly satisfied and dissatisfied), only 9 percent indicated satisfaction. The others were either fairly satisfied (37\%) or dissatisfied (54\%).

The results obtained from the estimates of the production frontier model showed that it was only the size of the land owned and the number of chickens sold that were significant (at $5 \%$ level). Land is a critical factor in indigenous chicken production. In general, the chicken-producing countries are more densely populated and have smaller land areas, while the cattle producing countries are larger and less populated. Free-ranging chicken require large tracts of land per household, just like is required for pastoralism. Decreasing land sizes per household signaled a need to increase feed supplements and breed improvement. Densely populated areas produce exotic layers and fast-growing broilers. Improved housing, disease and predator control, and predetermined market for outputs characterize intensive production. In urban areas, layers and broilers are kept because human populations are high with high income, but with inadequate land sizes for their own chicken production. Distances to this market are relatively short and input suppliers are within reach. With increase in human population in areas where households previously kept free-ranging indigenous chicken, the production approach must change. Newly improved indigenous breeds are now available in Kenya, but require additional attention than that required by the indigenous chickens. Demand for indigenous chicken is continuously rising but the potential to rear them is decreasing due to increased land sub-division. Households now have smaller land sizes.

Farmers in the study area operated at $74.83 \%$ technical efficiency. It was worth noting that over $97 \%$ of the indigenous chicken keepers operated between 60 and $90 \%$ technical efficiency. The minimum achieved efficiency level $(60.7 \%)$ was within the cluster and the maximum was a single farm at $91.3 \%$. The fact that the technical efficiencies of all the sampled indigenous chicken keeping households were less than $100 \%$, the implication was that no farm reached the frontier of production. This indicates that the indigenous keeping households have the potential to increase production efficiency. The finding revealed that indigenous chicken keepers could increase their number from the current 17 to 23 , without extra inputs or cost. Variations in the technical efficiencies among households may arise from farm characteristics that affect the ability of the chicken keeper to use the existing technology adequately.

\section{Conclusion}

The results of the study revealed that the indigenous chicken keeping households owned an average total of 17 at a time, after selling out about 15 for incomes. They produced an average of 500 eggs per annum, with each hen producing about 45 . Households consumed both eggs and chicken. The value of the sold and consumed eggs as well as sold chicken 
was Ksh. 17715 (1 USD= Ksh. 107). Most household heads were married (85\%), with $70 \%$ aged between 36 and 65 years. A majority of the farmers were literate (90\%). Over $75 \%$ of the households had between 3 and 6 persons. The average size of land owned was 1.33 acres. It's only $9 \%$ of farmers who were satisfied with farming. Decrease in land size prompted households to increase the flock sizes (tended towards commercialization). The number of live chickenssold correlated positively with increase in the number of indigenous chickens kept, but inversely proportional to land size owned. The study established that farmers operated at $74.83 \%$ technical efficiency implying that they could increase their flock from an average of 17 to 23 through better use of available resources, given the current state of technology without extra cost. It was recommended that since market for live indigenous chicken was in existence, approaches that assist in improving the chicken population be adopted. Use of genetically improved indigenous breeds, improvement of chickenhousing, supplementing the free-range feed with concentrate feed, improving egg hatchability and chick survival, require being considered. Improving farmer knowledge through better public extension service would be a pre-requisite for increased number of indigenous chicken flock size.

\section{Acknowledgements}

The South Korean Rural Development Administration (RDA) through the Korean Project for International Assistance (KOPIA), Kenya Centre, funded the data collection activity. The assistance is beyond support for data collection, for the funding covers for the cost of implementing the project in the three villages ( $\mathrm{Ng}^{\prime}$ onyi, Ntalami and Kangeta) under; 'Promotion of Indigenous Poultry Production for Food Security and Wealthy Creation among Smallholder Farmers in Meru County', between 2020 and 2022.

\section{References}

i. Aigner, D.C., Lovell, K., \& Schmidt, P. (1977). Formulation and Estimation of Stochastic Frontier Production Function Models. Journal of Econometrics, (6), 21-37

ii. Chirwa, W. E. (2007, November). Sources of Technical Efficiency Among Smallholder Maize Farmers in Southern Malawi. Nairobi: African Economic Research Consortium

iii. FAO. (2019). Livestock Primary Production Data. Retrieved from FAOSTAT: http://www.fao.org/faostat/en/\#data/QL

iv. FAO. (2017). H5N8 HPAI in Uganda. Retrieved from FAO: http://www.fao.org/3/a-i7105e.pdf

v. FAO. (2004). Small-Scale Poultry Production. Technical Guide. Rome

vi. Farrell, M.J. (1957). "The measurement of Productive Efficiency'. Journal of the Royal: Statistical Society. A CXX, Part (3)

vii. Fisseha, M., Azage, T., and Tadelle, D. (2010). Indigenous Chicken Production and Marketing Systems in Ethiopia: Characteristics and Opportunities for Market Oriented Development. IPMS (Improving Productivity and Market Success) of Ethiopian Farmers Project Working Paper 24. Nairobi, Kenya. ILRI. Accessed via www.ipms-ethiopia.org [on 25 May 2020].

viii. Guyonnet, V. (2017). Opportunities to Grow the Egg Business in Africa. Poultry Africa 2017. Kigali: FFI Consulting

ix. Jaetzold, R., Schmidt, H., Hornetz, B., and Shisanya, C. (2007). Farm Management Handbook of Kenya Vol. II; Natural Conditions and Farm Management Information. Nairobi: Ministry of Agriculture

x. Khai, H. V., \& Yabe, M. (2011). Technical Efficiency Analysis of Rice Production in Vietnam. Journal of ISSAAS, 17(1), 135-146

xi. KNBS. (2018). Kenya National Bureau of Statistics Report. Nairobi, Kenya

xii. Kokkinou, A., \& Geo.(2009). Stochastic frontier analysis: Empirical Evidence on Greek Productivity. Glasgow. University of Glasgow

xiii. Kumbhakar, S.C., \& Lovell, C.A.K. (2000). Stochastic Frontier Analysis. New York: Cambridge University Press

xiv. Kusina, J. F., N. T. Kusina and F. Mhlanga. 2001. A Survey on Village Chicken Losses: Causes and Solutions as Perceived by Farmers (Ed. R. G. Alders and P. B Spradbrow), Proceedings of SADC Planning Workshop on Newcastle Disease Control in Village Chickens, Maputo, Mozambique, 6-9 March 2000, Australian Center for International Agricultural Research. Canberra Proceedings 103, 148-155

xv. Mailu, S.K., Wachira, M.A., Munyasi, J.W., Nzioka, M., Kibiru, S.K., Mwangi, D.M., Kaguthi, P. \& Kithome, J. (2012). Influence of Prices on Market Participation Decisions of Indigenous Poultry Farmers in Four Districts of Eastern Province, Kenya: Journal of Agriculture and Social Research (JASR) Vol. 12, No. 1

xvi. Mandal, M.K.,Khandekar, N. and Khandekar, P. (2006). Backyard Poultry Farming in Bareilly District of Uttar Pradesh, India: An Analysis. Livestock Research for Rural Development, 18 (7) 2006. http://www.cipav.org.co/lrrd/lrrdl 8/7/mandl 8101.htm

xvii. Mapiye, C., Mwale, M., Mupangwa, J.F., Chimonyo. M., Foti. Rand Mutenje, M.J. (2008).A Research Review of Village Chicken Production Constraints and Opportunities in Zimbabwe. University of Fort Hare, South Africa

xviii. Meeusen, W., and van den Broeck J. (1977). Efficiency Estimation from Cobb-Douglas Production Functions withComposed Error. International Economic Review 18:2, 435-444

xix. Missohou, A.,Dieye, P.N. and Talaki, E. (2002). Rural Poultry Production and Productivity in Southern Senegal. Livestock Research for Rural development, 14 (2) 2002. http://www.cipav.org.co/Irrd/Irrd 14/2/miss 142.htm

xx. Msami, H.M., Tounkara, K., Kavuria, F.M. and Minga, U.M. (2002). An Assessment of Impact of Selected Intervention on the Production of Family Poultry in Tanzania. In: The Third Research Co-ordination Meeting of 
the FAO/IAEA Co-ordinated Research Programme (CRP) on village poultry production held in conjunction with DANIDA in Quatre Bomes, Mauritius in 6-10 May, 2002

xxi. Msoffe, P.L.M., Mtambo, M.M.A., Minga, U.M., Gwakisa, P.S., Mdegela, R.H and Olsen, J.E. (2002). Productivity and Natural Disease Resistant Potential of Free-range Local Chicken Ecotypes in Tanga in Tanzania. Livestock Research for Rural Development 14 (3) 2002.http://www.cipav.org.co/Irrd/Irrd 14/3/msofl43.htm of 25/05/2020

xxii. Muchadeyi,F.C., Sibanda, S, Kusina, N.T., Kusina, J and Makuza, S. (2004). The village chicken production system in Rusinga District of Zimbabwe. Livestock Research for Rural Development, 16 (4) 2004. http://www.cipav.org.co/lrrd/lrrd 16/6/much 16040.htm, 14/02/2008

xxiii. Munyasi, J.W., Nzioka, M., Kabiru, S.K., Wachira, A., Mwangi, D., Kaguthi, P., Kithome, J. and Muthiani, E.N. (2009). Existing and Potential Market Opportunities for Indigenous Chicken in Greater Machakos and Makueni Districts, Paper Presented at the APSK symposium Sunset Hotel, Kisumu 22-23 April, 2009

xxiv. Mutua, B.M. (2018). Challenges Facing Indigenous Chicken Production and Adoption Levels of Biosecurity Measures in Selected Areas of Makueni County, Kenya. Unpublished MSc. Thesis. South Eastern Kenya University

xxv. Olwande, P.O. (2010). Assessing the Productivity of Indigenous Chicken in Southern Nyanza, Kenya. Undated MSc. Thesis, University of Nairobi

xxvi. Pedersen, C. V. 2002. Production of Semi-Scavenging Chickens in Zimbabwe. PhD Thesis. The Royal Veterinary and Agricultural University, Copenhagen, Denmark

xxvii. Reifschneider, D and Stevenson, R. (1991). Systematic Departures from the Frontier: A framework for the Analysis of Firm Inefficiency. International Economic Review, 32, 715-723

xxviii. Republic of Kenya (RoK). (2019). 2019 Kenya Population and Housing Census. Volume 1: Population by County and Sub-County

xxix. Sekeroglu, A. and Aksimsek, S.D. (2009). Village Chicken Production in Turkey: Tokat Province Example. Tropical Animal Health and Production 41, Pp.103-108. DOI 10.1007/sl 1250-008-9163-0

xxx. Ssewannyana, E., Onyait, A.O., Ogwal, O.J. and Masaba, J. (2006). Strategies for Improving the Meat and Egg Productivity of Indigenous Chickens in Kumi and Apac Districts, Uganda.Uganda Journal of Agricultural Sciences, 2006, 12(2): 31-35

xxxi. Siyaya and Masuku. (2013). Determinants of Profitability of Indigenous Chickens in Swaziland. University of Swaziland, Swaziland

xxxii. Technoserve and KARI. (Undated). Indigenous Chicken Production. Training Manual

xxxiii. Thwala, M. (2012). Analysing the Value Chain of the Family Poultry Subsector in the Lower Usuthu Project Area in Swaziland. SWADE. Siphofaneni. Swaziland. 